\title{
Sustaining productivity of a Vertosol at Warra, Queensland, with fertilisers, no-tillage or legumes. 8. Effect of duration of lucerne ley on soil nitrogen and water, wheat yield and protein
}

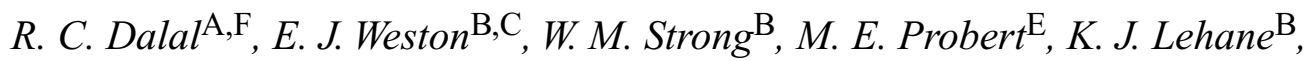 \\ J. E. Cooper ${ }^{\mathrm{B}}$, A. J. King ${ }^{\mathrm{D}}$ and C. J. Holmes ${ }^{\mathrm{D}}$ \\ ADepartment of Natural Resources and Mines, Indooroopilly, Qld 4068, Australia. \\ ${ }^{B}$ Farming Systems Institute, Department of Primary Industries, Toowoomba, Qld 4350, Australia. \\ CPresent address: 50 Broadwater Terrace, Redland Bay, Qld 4165, Australia. \\ DDepartment of Natural Resources and Mines, Toowoomba, Qld 4350, Australia. \\ ${ }^{E}$ CSIRO Sustainable Ecosystems, St Lucia, Qld 4067, Australia. \\ FCorresponding author. Email: Ram.Dalal@nrm.qld.gov.au
}

Abstract. Soil nitrogen (N) supply in the Vertosols of southern Queensland, Australia has steadily declined as a result of long-term cereal cropping without $\mathrm{N}$ fertiliser application or rotations with legumes. Nitrogen-fixing legumes such as lucerne may enhance soil $\mathrm{N}$ supply and therefore could be used in lucerne-wheat rotations. However, lucerne leys in this subtropical environment can create a soil moisture deficit, which may persist for a number of seasons. Therefore, we evaluated the effect of varying the duration of a lucerne ley (for up to 4 years) on soil $\mathrm{N}$ increase, $\mathrm{N}$ supply to wheat, soil water changes, wheat yields and wheat protein on a fertility-depleted Vertosol in a field experiment between 1989 and 1996 at Warra $\left(26^{\circ} 47^{\prime} \mathrm{S}, 150^{\circ} 53^{\prime} \mathrm{E}\right)$, southern Queensland. The experiment consisted of a wheat-wheat rotation, and 8 treatments of lucerne leys starting in 1989 (phase 1) or 1990 (phase 2) for 1, 2, 3 or 4 years duration, followed by wheat cropping. Lucerne DM yield and $\mathrm{N}$ yield increased with increasing duration of lucerne leys. Soil $\mathrm{N}$ increased over time following 2 years of lucerne but there was no further significant increase after 3 or 4 years of lucerne ley. Soil nitrate concentrations increased significantly with all lucerne leys and moved progressively downward in the soil profile from 1992 to 1995. Soil water, especially at $0.9-1.2 \mathrm{~m}$ depth, remained significantly lower for the next 3 years after the termination of the 4-year lucerne ley than under continuous wheat. No significant increase in wheat yields was observed from 1992 to 1995, irrespective of the lucerne ley. However, wheat grain protein concentrations were significantly higher under lucerne-wheat than under wheat-wheat rotations for 3-5 years. The lucerne yield and soil water and nitrate-N concentrations were satisfactorily simulated with the APSIM model. Although significant $\mathrm{N}$ accretion occurred in the soil following lucerne leys, in drier seasons, recharge of the drier soil profile following long duration lucerne occurred after 3 years. Consequently, 3- and 4-year lucerne-wheat rotations resulted in more variable wheat yields than wheat-wheat rotations in this region. The remaining challenge in using lucerne-wheat rotations is balancing the $\mathrm{N}$ accretion benefits with plant-available water deficits, which are most likely to occur in the highly variable rainfall conditions of this region.

Additional keywords: lucerne-wheat rotation, soil nitrogen fertility, soil water deficit, soil nitrate accumulation.

\section{Introduction}

Continuous cereal production in the cropping lands of subtropical Queensland has depleted these soils of total and plant-available nitrogen $(\mathrm{N})$ to the extent that wheat yields and protein levels are not commensurate with plant-available water and rainfall (Dalal and Mayer 1986a, 1986c; Dalal et al. 1991). Strategies to improve these systems include the application of fertilisers, changes in tillage techniques, the use of grain legumes, and the development of crop-pasture rotations (Dalal et al. 1995, 1998, 2004; Strong et al. 1996; Weston et al. 2002). There is currently much interest in rotational cropping systems involving legumes as a source of N (Hossain et al. 1996a; Holford and Crocker 1997; Dalal et al. 1998; Holford et al. 1998; Armstrong et al. 1999; Weston et al. 2002).

Holford et al. (1998) and Weston et al. (2002) showed that the temperate annual pasture legume, annual medic, significantly increased available $\mathrm{N}$, grain yields and protein content of subsequent wheat crops in the subtropics. However, it could be expected that perennial legumes such as lucerne (Medicago sativa) may perform better than wintergrowing annual medics due to summer-dominant rainfall in 
the subtropical northern New South Wales and Queensland region (Hossain et al. 1996b; Holford et al.1998; Weston et al. 2000).

The amount of $\mathrm{N}$ fixed by lucerne is closely associated with the total amount of dry matter (DM) produced (Peoples and Baldock 2001), and therefore, $\mathrm{N}$ benefits to subsequent wheat crops depend on the productivity of the legumes in the ley period. Using the $\delta^{15} \mathrm{~N}$ natural abundance method, Hossain et al. (1995) found that $60 \mathrm{~kg} / \mathrm{ha}$ of $\mathrm{N}$ was fixed by lucerne in aboveground DM at Warra, southern Queensland in 1988. Following the lucerne ley, a substantial increase in mineral $\mathrm{N}$ was also observed (Hossain et al. 1996a) and this was reflected in increased wheat grain yield and protein in 1989 (Hossain et al. 1996b). In a long-term experiment from 1988 to 1998 using a 2-year lucerne-wheat rotation, Dalal et al. (2004) also observed significant increases in soil total $\mathrm{N}$ and mineral $\mathrm{N}$ following lucerne leys in most but not all years. Consequently, higher wheat grain protein in 7 seasons and grain yield in 4 out of 9 seasons were produced compared with wheat-wheat rotations. Whitehouse and Littler (1984) found that 2 years of lucerne produced the maximum increases in total soil N. Holford (1981) recommended a minimum of 2.5 years of lucerne to increase initial soil $\mathrm{N}$ although soil $\mathrm{N}$ levels in both studies were almost twice that in the Warra experiment $(0.13 v .0 .06 \% \mathrm{~N})$. Because seasonal variability is a strong feature of the subtropical environment, it was necessary to measure lucerne production, its fertility restoration benefit and wheat crop yields over a longer period than we reported for the 2-year lucerne-wheat rotation in the previous study (Dalal et al. 2004).

We report here on the results of a field experiment comparing the effects of $1,2,3$ or 4 years of lucerne ley followed by wheat on total lucerne biomass production, legume $\mathrm{N}$ accretion, available $\mathrm{N}$, water use, wheat grain yields and wheat protein content. To assess the frequency of the ley pasture benefits reported, we have applied the APSIM model (Keating et al. 2003) to evaluate the probability with which a lucerne ley affects the availability of water and $\mathrm{N}$ for subsequent wheat crops.

\section{Materials and methods}

Site details

The studies were carried out at Warra $\left(26^{\circ} 47^{\prime} \mathrm{S}, 150^{\circ} 53^{\prime} \mathrm{E}\right)$ in southern Queensland, adjacent to the previously reported 2-year lucerne-wheat rotation experiment (Dalal et al. 2004). Soil at the site has been cultivated for cereal cropping since about 1935, after it was cleared of the native brigalow (Acacia harpophylla) and belah (Casuarina cristata) vegetation. Since that time, the organic matter of this Vertosol (Typic Chromustert) has been depleted from 2.23 to $0.68 \%$ $\mathrm{OC}$ and from 0.203 to $0.06 \%$ total $\mathrm{N}$ in the $0-10 \mathrm{~cm}$ layer (Dalal and Mayer 1986b, 1986c). Details of the soil characteristics, mean monthly minimum and maximum temperatures, and mean monthly rainfall are described in earlier papers of this series (Dalal et al.1995; Strong et al. 1996; Weston et al. 2002). Briefly, the soil is alkaline at the surface (pH 8.6) trending to strongly acidic ( $\mathrm{pH} 4.9)$ at $1.2 \mathrm{~m}$ depth, and contains $56 \%$ clay. Mean annual rainfall varied from $396 \mathrm{~mm}$ in $1986(35 \%$ below average) to $767 \mathrm{~mm}$ in 1996 (30\% above average).

\section{Experimental design}

The experiment consisted of 9 treatments, including lucerne leys initiated in 2 years, and replicated 3 times in a randomised block design. The treatments were wheat-wheat rotations, and lucerne leys starting in 1989 (phase 1) and 1990 (phase 2) for 1, 2, 3 or 4 years duration, followed by wheat cropping (Table 1). Pasture establishment, its management, and soil and plant measurements were performed in the same manner and time as for the adjacent 2-year lucerne-wheat rotation (Dalal et al. 2004). A brief description is given below.

\section{Pasture establishment}

Wheat was undersown with lucerne (cv. Trifecta, $2 \mathrm{~kg} / \mathrm{ha}$ ) in 1988 to provide a lucerne ley in 1989 (phase 1) and wheat undersown with lucerne $(2 \mathrm{~kg} / \mathrm{ha})$ in 1989 provided a lucerne ley in 1990 (phase 2) for $1,2,3$ or 4 years duration. Sowing time for wheat and undersown lucerne was generally May or June depending on sowing rains.

\section{Pasture management and measurements}

Lucerne leys were forage-harvested to a height of $0.1 \mathrm{~m}$ at 3-monthly sampling intervals (December, March, June and September). Lucerne pasture leys were terminated in early October by bladeploughing to $0.10-0.15 \mathrm{~m}$ depth, at the start of the summer fallow. This was considered to be an optimum period to terminate the lucerne, to allow the recharge of the soil profile by mid-late spring storms and summer and autumn rainfall, as well as to optimise lucerne DM. Early termination of lucerne in late August-September reduces lucerne DM and $\mathrm{N}$ fixation but rarely results in additional water in the soil profile

Table 1. The lucerne-wheat sequence from 1988 to 1996

W, wheat; $\mathrm{W}_{\mathrm{L}}$, wheat undersown lucerne; L, lucerne; F, fallow, no crop sown due to drought; treatments 1, 2, 5 and 9 were fallowed in 1991

\begin{tabular}{|c|c|c|c|c|c|c|c|c|c|}
\hline \multirow[t]{2}{*}{ Treatment } & \multicolumn{9}{|c|}{ Lucerne--wheat sequence } \\
\hline & 1988 & 1989 & 1990 & 1991 & 1992 & 1993 & 1994 & 1995 & 1996 \\
\hline 1. Lucerne 1 (1989) & $\mathrm{W}_{\mathrm{L}}$ & $\mathrm{L}$ & W & $\mathrm{F}$ & W & W & W & W & W \\
\hline 2. Lucerne 1 (1989-90) & $\mathrm{W}_{\mathrm{L}}^{\mathrm{L}}$ & $\mathrm{L}$ & $\mathrm{L}$ & $\mathrm{F}$ & W & W & W & W & W \\
\hline 3. Lucerne 1 (1989-91) & $\mathrm{W}_{\mathrm{L}}^{\mathrm{L}}$ & $\mathrm{L}$ & $\mathrm{L}$ & $\mathrm{L}$ & W & W & W & W & W \\
\hline 4. Lucerne 1 (1989-92) & $\mathrm{W}_{\mathrm{L}}^{\mathrm{L}}$ & $\mathrm{L}$ & $\mathrm{L}$ & $\mathrm{L}$ & $\mathrm{L}$ & W & W & W & W \\
\hline 5. Lucerne 2 (1990) & W & $\mathrm{W}_{\mathrm{L}}$ & $\mathrm{L}$ & $\mathrm{F}$ & $\mathrm{W}$ & W & W & W & W \\
\hline 6. Lucerne 2 (1990-91) & W & $\mathrm{W}_{\mathrm{L}}^{\mathrm{L}}$ & $\mathrm{L}$ & $\mathrm{L}$ & W & W & W & W & W \\
\hline 7. Lucerne 2 (1990-92) & W & $\mathrm{W}_{\mathrm{L}}^{\mathrm{L}}$ & $\mathrm{L}$ & $\mathrm{L}$ & $\mathrm{L}$ & W & W & W & W \\
\hline 8. Lucerne 2 (1990-93) & W & $\mathrm{W}_{\mathrm{L}}^{\mathrm{L}}$ & $\mathrm{L}$ & $\mathrm{L}$ & $\mathrm{L}$ & $\mathrm{L}$ & W & W & W \\
\hline 9. Continuous wheat & W & W & $\mathrm{W}$ & $\mathrm{F}$ & W & W & W & W & W \\
\hline
\end{tabular}


due to the low amount of rainfall received during this period. Moreover, after early spring growth of lucerne, the topsoil was relatively dry, which ensured that the lucerne kill by blade-ploughing was complete.

At quarterly intervals, in March, June, September and December, lucerne (and weeds, if present) was sampled for DM yield and $\mathrm{N}$ concentration. Five quadrats of 1 by $1 \mathrm{~m}$ were used for sampling from each plot. At the termination of the lucerne ley in October, an additional DM measurement was made. Plant material was dried at $75^{\circ} \mathrm{C}$, weighed and ground to pass through a $1 \mathrm{~mm}$ sieve and DM \% determined by Kjeldahl analysis (Crooke and Simpson 1971).

Just before harvesting the quadrats for lucerne DM, plant counts were made at each quarterly interval. The average lucerne plant numbers in September each year varied from 8 to 18 plants $/ \mathrm{m}^{2}$ except in the dry year of 1991 when the plant populations were $6-8$ plants $/ \mathrm{m}^{2}$.

\section{Crop and soil management}

Wheat plots were fallowed using stubble retention machinery (Strong et al. 1996). Following a 6-7 month summer fallow, wheat (cv. Hartog) was sown $(0.25 \mathrm{~m}$ row spacing) at a rate of $40 \mathrm{~kg} / \mathrm{ha}$ when sown in May or June or $50 \mathrm{~kg} /$ ha when sown in July 1990 and 1993. Little weed control was required during wheat cropping since no lucerne plants survived the blade-ploughing of relatively dry soil. Fertiliser $\mathrm{N}$ was not applied and the undersown lucerne contributed only a small amount of $\mathrm{DM}$ and $\mathrm{N}$ to the overall rotation during the experimental period.

A basal rate of $10 \mathrm{~kg}$ of phosphorus/ha as superphosphate, fortified with copper and zinc, was applied to wheat at sowing each year. Pastures were topdressed with the same fertiliser and at the same rate annually.

\section{Crop measurements}

Aboveground DM yields were estimated just before wheat harvest from $1 \mathrm{~m}$ lengths of 2 adjacent plant rows. After drying at $75^{\circ} \mathrm{C}$, grain and straw were separated and the weights of each were recorded. Grain yield was determined by machine harvesting an inside $8 \mathrm{~m}$ length of the central 7 rows of each plot after trimming both ends of a plot. Grain yields were adjusted to $12 \%$ moisture content and the $\% \mathrm{~N}$ in grain and straw was determined by Kjeldahl analysis (Crooke and Simpson 1971).

\section{Soil sampling and analyses}

Soil was sampled biannually in May and November to a depth of $1.5 \mathrm{~m}$ for soil water and nitrate content. Two soil cores of $50 \mathrm{~mm}$ diameter were pooled by $0.1 \mathrm{~m}$ layers to a depth of $0.3 \mathrm{~m}$, and pooled by $0.3 \mathrm{~m}$ layers below this depth, and stored at $4^{\circ} \mathrm{C}$ until analysis. Soil was dried at $35^{\circ} \mathrm{C}$ under draught, and ground to $<2 \mathrm{~mm}$ for colorimetric determination of nitrate (Best 1976) after extraction of $10 \mathrm{~g}$ of soil in $100 \mathrm{~mL}$ of $2 \mathrm{~mol} / \mathrm{L} \mathrm{KCl}$. Soil moisture content was determined gravimetrically and converted to volumetric soil moisture content ( $\mathrm{mm} /$ layer) using a bulk density adjusted for the soil moisture content for the layer (Strong et al. 1996). Plant-available water was derived by subtracting soil water content at the estimated lowest limit of availability for each soil layer from the measured volumetric water content (lowest water content between 1987 and 1994). The maximum amounts of measured plant-available water (difference between the lowest and highest water contents between 1987 and 1994) for $0-0.1 \mathrm{~m}$, 0-0.2 m, 0-0.3 m, 0-0.6 m, 0-0.9 m, 0-1.2 m, and 0-1.5 m depths were $22,44,65,127,178,221$, and $258 \mathrm{~mm}$, respectively.

From November 1990 onwards, monthly soil moisture measurements were made using a neutron moisture metre, after calibrating against the measured volumetric soil moisture contents from May and November samplings.

Soil was sampled annually in May (5 composite samples from each plot) to a depth of $0.1 \mathrm{~m}$ to determine total $\mathrm{N}$ by a modified Kjeldahl method (Dalal et al. 1984) after fine grinding to $<0.25 \mathrm{~mm}$.
Predicting wheat grain protein from presowing soil water and nitrate

Presowing plant-available water and nitrate in soil (0-1.2 m depth) was used to predict wheat grain protein following lucerne ley. The relationship between grain protein and the ratio of plant-available water $(\mathrm{mm})$ to nitrate $(\mathrm{kg} / \mathrm{ha})$, developed by Dalal et al. (1997) from the southern Queensland wheat and barley field trials, was used to examine if grain proteins could be predicted at sowing. The relationship between grain protein and the ratio of plant-available water $(\mathrm{mm})$ to nitrate $(\mathrm{kg} / \mathrm{ha})$ is:

Grain protein $(\%)=6.52+10.0 \exp (-0.44$ available water/nitrate-N)

The grain proteins calculated using the above equation were then correlated with the measured grain proteins for all the wheat crops (1988-96) grown in this study.

\section{Simulation modelling}

The APSIM (Agricultural Production System Simulator, Keating et al. 2003) model was used to simulate the lucerne-wheat rotation system using the lucerne and wheat (Nwheat) modules. The core experiment at Warra has been extensively used to test aspects of the APSIM modelling framework, especially the dynamics of soil water and $\mathrm{N}$ under a sequence of crops including the 2-year wheat-lucerne rotations (Probert et al. 1998; Turpin et al. 1998). The soil water characteristics were estimated from the measured data using the treatment means of the 4 replicates. The wettest measured data provided the basis for the drained upper limit (DUL), while the lower limit of extraction of water for lucerne and wheat when grown with adequate $\mathrm{N}$ were derived from the lowest observed water contents. Lucerne was capable of drying the soil to lower water contents than wheat, especially in the deeper layers. Based on the parameter set used for APSIM, the plant-available water content to $1.5 \mathrm{~m}$ was $258 \mathrm{~mm}$ for lucerne and $199 \mathrm{~mm}$ for wheat. Here we have applied the parameters derived for the treatments of the core experiment (Dalal et al. 2004) to predict behaviour under different lengths of lucerne ley.

A significant feature of the experimental data is that following lucerne, the soil profile often does not re-wet to rooting depth before the subsequent wheat crop. The model is well suited to address how often this would occur, and the extent to which the time of terminating the lucerne phase influences following crops. The scenario presented here is for a 2-year lucerne ley established by under-sowing with wheat, and followed by wheat crops, for the Warra soil and using the long-term (1887-97) weather file for Dalby (http:/www.dnr.qld.gov.au/silo). The simulations were run so that there was output for lucerne in every year of the weather file. The model was reset so that soil organic matter and crop residues were identical after each harvest of the wheat crop preceding the establishment of the lucerne leys.

\section{Results}

\section{Aboveground dry matter production and nitrogen yield}

Cumulative lucerne DM yield increased when the duration of lucerne leys increased from 1 year to 2, 3 or 4 years (Fig. 1). Except for the 1-year lucerne ley, lucerne leys established in 1989 and 1990 had similar DM yields. During October-March, the phase 1 lucerne ley in 1989 received much less rainfall $(301 \mathrm{~mm})$ than the phase 21 -year lucerne $(430 \mathrm{~mm})$, resulting in almost twice the growth by the latter $(1.82 v .3 .56 \mathrm{t} / \mathrm{ha})$. This large difference in lucerne production did not persist for the 2, 3 or 4-year leys, apparently being offset by subsequent growing conditions.

Trends in lucerne $\mathrm{N}$ yields followed that of lucerne DM yields [Fig. 1, lucerne $\mathrm{N}(\mathrm{kg} / \mathrm{ha})=9.4+28.6 \mathrm{DM}(\mathrm{t} / \mathrm{ha})$; $\left.r^{2}=0.99\right]$, with $29 \mathrm{~kg} \mathrm{~N} / \mathrm{t}$ DM. There was a minor contribution of DM and $\mathrm{N}$ from weed growth. 
Both annual DM yields and $\mathrm{N}$ yields were significantly correlated with the total rainfall. Each millimetre of total growing period rainfall (October-September) increased DM by $5 \mathrm{~kg} / \mathrm{ha}\left(r^{2}=0.63\right)$ and $\mathrm{N}$ yields by $0.12 \mathrm{~kg} \mathrm{~N} / \mathrm{ha}$ $\left(r^{2}=0.43\right)$.

\section{Total soil nitrogen}

One-year lucerne in 1989 showed no significant increase in soil $\mathrm{N}$ but 2, 3 and 4-year lucerne caused a significant increase (Fig. 2); maximum increase in soil $\mathrm{N}$ from the 4-year lucerne ley in phase 1 was $123 \mathrm{~kg} \mathrm{~N} / \mathrm{ha}$. Total soil N concentrations after the wheat harvest in November 1996 were $13-103 \mathrm{~kg} \mathrm{~N} / \mathrm{ha}$ more in lucerne-wheat rotations than in continuous wheat cropping, although these values were not significantly different than that from the latter treatment because of large variations [1.s.d. $(P=0.05), 121 \mathrm{~kg} \mathrm{~N} / \mathrm{ha}]$.

\section{Available nitrogen}

Available N under lucerne remained low ( $<40 \mathrm{~kg} \mathrm{~N} / \mathrm{ha}$ in $0-1.5 \mathrm{~m}$ depth) throughout the lucerne growing periods. For example, both phases of 4-year lucerne contained $<40 \mathrm{~kg} \mathrm{~N} / \mathrm{ha}$ compared with $106 \mathrm{~kg} \mathrm{~N} / \mathrm{ha}$ in wheat-wheat rotations, mostly in the top $0.9 \mathrm{~m}$ depth (Fig. 3). However, 8 months after the termination of lucerne in phase 1 , a significant amount of $\mathrm{N}$ had mineralised in the top $0.3 \mathrm{~m}$ depth $(79 \mathrm{~kg} \mathrm{~N} / \mathrm{ha})$, compared with $20 \mathrm{~kg} \mathrm{~N} / \mathrm{ha}$ in the continuous wheat. Since available N was used only poorly by the wheat, the growth of which was limited by available water, significant nitrate- $\mathrm{N}$ accumulated in deeper soil layers

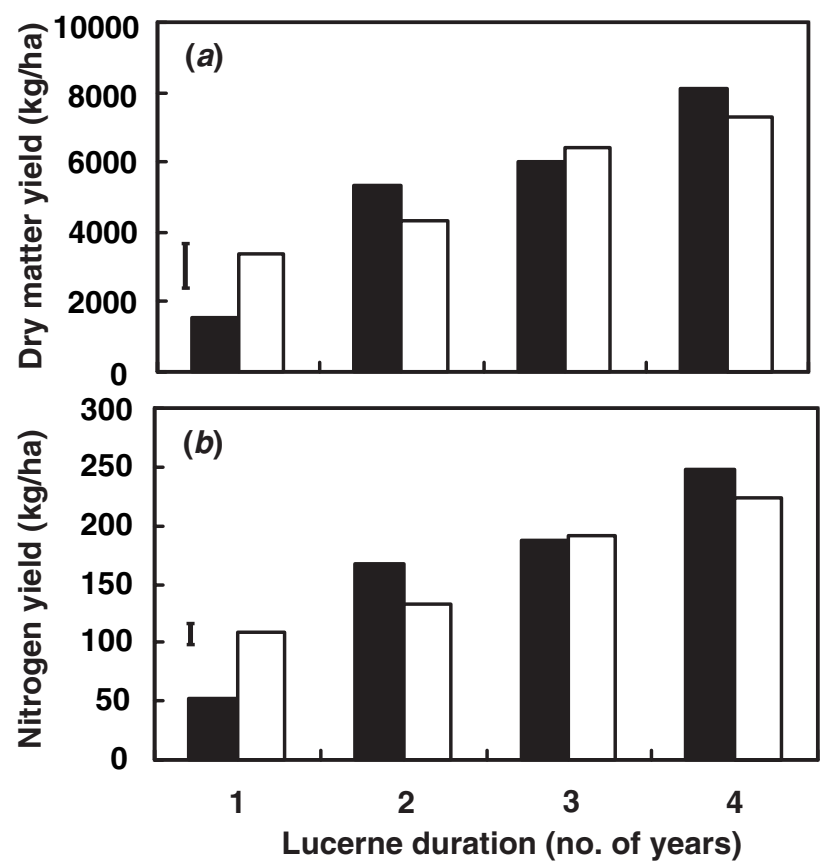

Figure 1. Effect of lucerne leys on total aboveground biomass yield and $\mathrm{N}$ yield. Vertical bars indicate 1.s.d. $(P=0.05)$. Solid bars, leys in phase 1 commenced in 1989; open bars, leys in phase 2 commenced in 1990. in the following years. For example, nitrate-N was significantly higher at $0.6-0.9 \mathrm{~m}$ depths in May 1996 previously under lucerne $(35 \mathrm{~kg} \mathrm{~N} / \mathrm{ha})$ than in wheat-wheat rotations (11 kg N/ha) (Fig. 3).

\section{Plant-available water}

Plant-available water decreased to very low values during lucerne growth so that by the end of the lucerne leys, plantavailable water was significantly lower than wheat down to $1.5 \mathrm{~m}$ depth. This is shown for the 2- and 4-year duration lucerne leys compared with wheat-wheat rotations (Fig. 4). In May 1992, <60 mm of water was available after a 4-year lucerne ley compared with $120 \mathrm{~mm}(0-1.5 \mathrm{~m}$ depth) after wheat (Fig. 4). After 4 years of lucerne ley, the soil profile contained less water in deeper layers, $0.9-1.2$ and $1.2-1.5 \mathrm{~m}$ (Fig. 3), and this water deficit persisted in the deepest layer until 1996 (Figs 3 and 4). These water deficits were reflected in wheat grain yields and proteins following lucerne.

\section{Grain yield and grain protein}

Compared with continuous wheat, wheat grain yield significantly increased in the first year following the 1-year lucerne (removed in 1989) but there were no increases in the following 4 wheat crops (1992, 1993, 1994 and 1995), although in 1996 (with improved soil moisture) grain yield again was higher than that of the wheat-wheat rotations (Table 2). Similar results were observed with 2, 3 and 4-year lucerne removed during 1990-93, with the exception that while $\geq 2$-year lucerne showed much depressed grain yields in 1995, the 1-year lucerne from phase 1, had similar yields to that of continuous wheat. The 1991-95 period was dry and wheat yields were limited by available water. Following good seasonal conditions in 1996, however, wheat grain yields were significantly greater from all lucerne leys compared

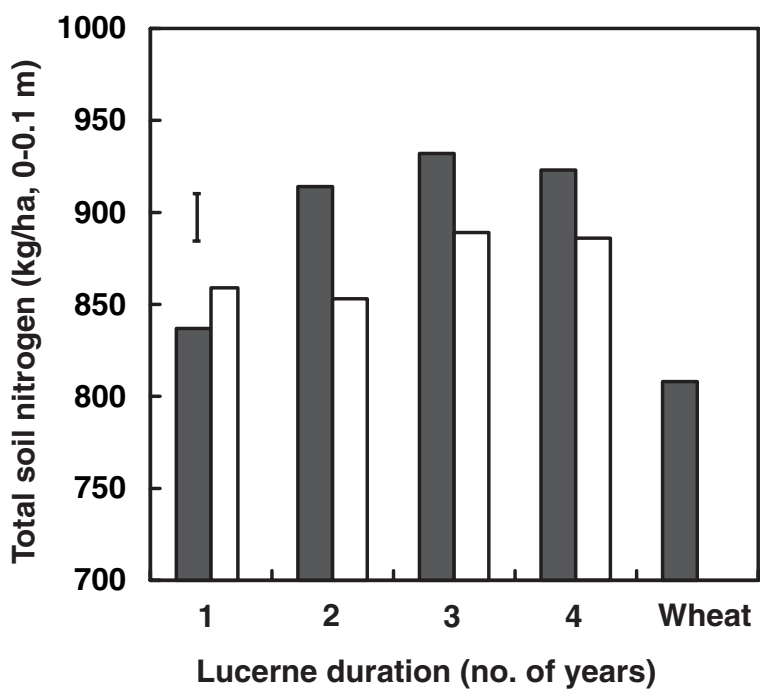

Figure 2. Effect of lucerne leys on total soil $\mathrm{N}(0-0.1 \mathrm{~m}$ depth). Vertical bar indicates 1.s.d. $(P=0.05)$. Solid bars, leys in phase 1 commenced in 1989; open bars, leys in phase 2 commenced in 1990. 
with continuous wheat, and showed an increasing yield trend with increasing lucerne ley. As the lucerne leys increased from 1 to 2, 3 and 4 years (phase 1), after 5, 4, 4, and 3 wheat crops were taken, respectively, the corresponding increases in wheat yields in 1996 were 3.0 to $3.24 \mathrm{t} / \mathrm{ha}, 3.42$ and $3.60 \mathrm{t} / \mathrm{ha}$. In phase 2 of the lucerne ley, however, after 4, 4, 3 and 2 wheat crops were taken from the 1 to 2, 3 and 4-year lucerne leys, respectively, the lucerne duration had no significant effect, with all lucerne leys increasing wheat yields similarly.

Wheat grain protein concentrations were significantly increased following the lucerne leys (Table 3). A 1-year lucerne ley from phase 1 increased grain protein in the 2 subsequent wheat crops while a 1-year lucerne ley in
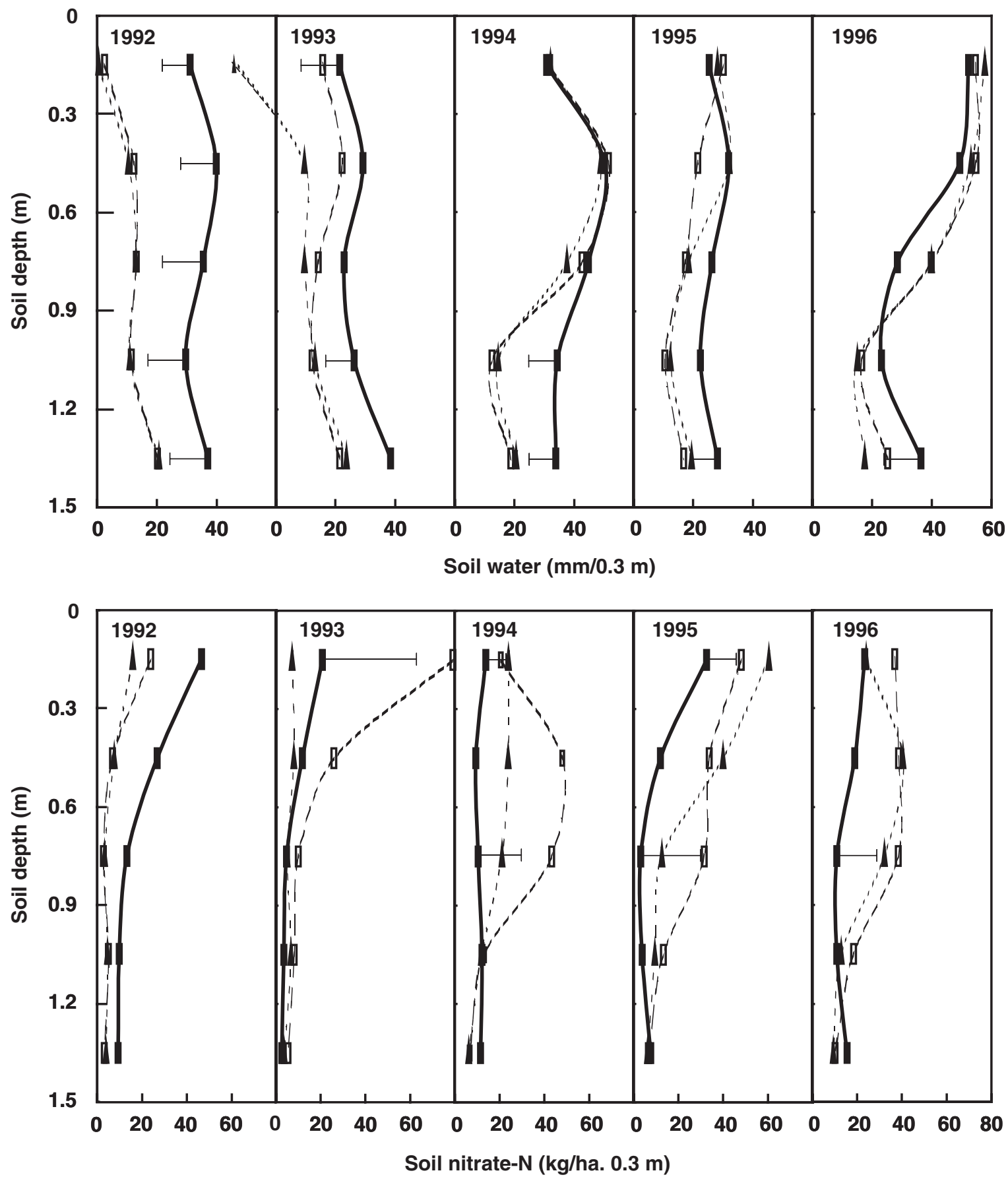

Figure 3. Distribution of plant-available water and nitrate- $\mathrm{N}$ in the soil profile in May (presowing for wheat), measured after 6 months summer fallow following lucerne leys (- - lucerne ley in phase 1, 1989-1992; - - lucerne ley in phase 2, 1990-1993) in lucerne-wheat rotations and wheat-wheat rotations with $0 \mathrm{~kg} \mathrm{~N} /$ ha fertiliser application (- - . The horizontal bar width represents 1.s.d. $(P=0.05)$. 


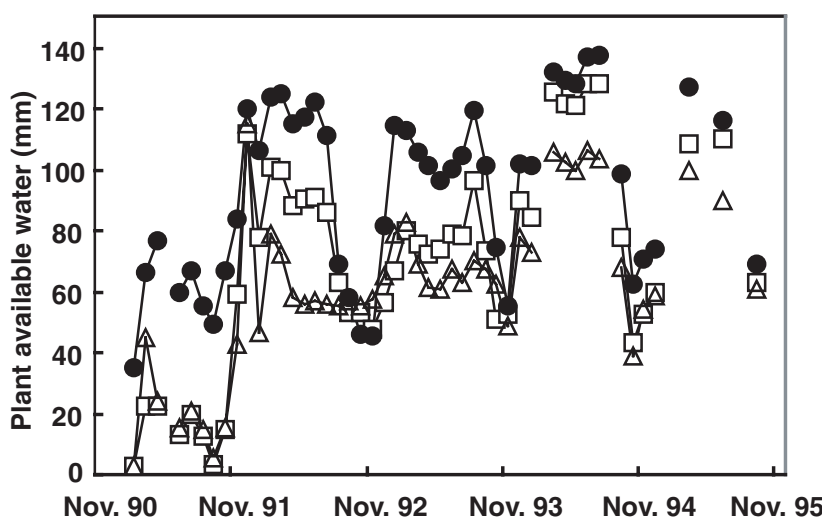

Figure 4. Trends in plant-available water in soil following a 2-year lucerne ley $(\square)$, a 4-year lucerne ley $(\triangle)$ and a wheat-wheat rotation (O) from 1990 to 1995.

phase 2 and 2, 3 and 4-year lucerne leys in both phases, increased grain protein concentrations in almost all years of wheat cropping. The only exception was the similarity in grain protein content between continuous wheat and the 2 -year lucerne ley from phase 2 in 1996, the fifth wheat crop after termination of the lucerne ley.

There was a close relationship between the amount of available water (presowing plant-available water in soil to $0-1.2 \mathrm{~m}$ depth + rainfall from sowing to anthesis) and wheat grain yield $\left(r^{2}=0.8\right.$, Fig. 5). However, there was a poor correlation between the presowing available water in soil and grain yield $\left(r^{2}=0.22\right)$, total amount of available water (presowing plant-available water in soil to $0-1.2 \mathrm{~m}$ depth + total in-crop rainfall) and grain yield $\left(r^{2}=0.24\right)$, and nitrate-N and grain yield $\left(r^{2}=0.04\right)$. While wheat grain protein decreased with increasing presowing available water in soil $\left(r^{2}=0.51\right)$, it increased with increasing amounts of nitrate in the soil $\left(r^{2}=0.43\right)$. The relationship between presowing available water, nitrate and grain protein improved substantially when the ratio of presowing available water to nitrate was correlated with grain protein, using the relationship developed by Dalal et al. (1997) $\left(r^{2}=0.74\right.$, Fig. 6).

\section{Simulation of the lucerne-wheat system}

The ability of the APSIM model to predict the observed growth of the crops is illustrated in Figure 7 for the 4-year lucerne (phase 2) treatment and the continuous wheat without fertiliser N. The goodness of fit of the model was satisfactory for the wheat yields. This is achieved because the model captures satisfactorily the changes through time in both soil water and nitrate-N. Of particular note:

- Lucerne exhausts the available soil water to $1.5 \mathrm{~m}$ within 2 or 3 years. Beneath $1.5 \mathrm{~m}$, the Warra soil is quite acidic, pH 4.4 (Page et al. 2002), which we presume limits the rooting depth of wheat although lucerne appears to extract water to $2.1 \mathrm{~m}$ depth (Hossain et al. 1996a).

- Under a lucerne ley, nitrate-N remained low until the legume was removed in October 1992, after which there was a rapid increase in mineralisation to higher values than exist under continuous wheat. The effect of the ley in mineralising $\mathrm{N}$ persists for several years although there is some indication that the model underestimated this, especially before the 1995 wheat crop. Note also the continuing mineralisation of $\mathrm{N}$ through the long fallow of November 1990-May 1992 when the wheat crop for the continuous wheat treatment could not be sown.

- The model sometimes failed to capture observed variation in the wheat protein data. This was most obvious in 1992, when soil $\mathrm{N}$ supply was high after the long fallow, and in 1995 for the 2 treatments when wheat yields were limited by inadequate soil water and in-crop rainfall.

\section{Discussion}

\section{Lucerne dry matter production and nitrogen yield}

Seasonal rainfall conditions were the major contributing factor to the lucerne production pattern, and hence to the $\mathrm{N}$ yield. The lucerne DM yield for each $\mathrm{mm}$ of rainfall received during lucerne growth $(5 \mathrm{~kg} / \mathrm{mm})$ was lower than that observed for lucerne in a 2-year lucerne-wheat rotation $(9.7 \mathrm{~kg} / \mathrm{mm})($ Dalal et al. 2004) and that by Lloyd and Hilder (1978) at Kingsthorpe, Queensland (5.5-11.9 kg/mm). Lloyd and Hilder's (1978) result was presumably due to the

Table 2. The effect of duration of lucerne on grain yields of the following wheat crop

L, lucerne; F, fallow, no crop sown due to drought

\begin{tabular}{lccccccccc}
\hline Treatment & \multicolumn{1}{c}{ Wheat grain yield at 12\% moisture (t/ha) } \\
& 1988 & 1989 & 1990 & 1991 & 1992 & 1993 & 1994 & 1995 & 1996 \\
\hline 1. Lucerne 1 (1989) & 4.80 & $\mathrm{~L}$ & 3.41 & $\mathrm{~F}$ & 3.13 & 1.99 & 1.36 & 1.08 & 3.00 \\
2. Lucerne 1 (1989-90) & 4.62 & $\mathrm{~L}$ & $\mathrm{~L}$ & $\mathrm{~F}$ & 2.52 & 1.95 & 1.34 & 0.78 & 3.24 \\
3. Lucerne 1 (1989-91) & 4.74 & $\mathrm{~L}$ & $\mathrm{~L}$ & $\mathrm{~L}$ & 2.64 & 1.86 & 1.29 & 0.73 & 3.42 \\
4. Lucerne 1 (1989-92) & 4.52 & $\mathrm{~L}$ & $\mathrm{~L}$ & $\mathrm{~L}$ & $\mathrm{~L}$ & 1.79 & 1.41 & 0.64 & 3.60 \\
5. Lucerne 2 (1990) & 4.90 & 2.17 & $\mathrm{~L}$ & $\mathrm{~F}$ & 2.92 & 1.87 & 1.11 & 0.83 & 3.43 \\
6. Lucerne 2 (1990-91) & 4.93 & 2.21 & $\mathrm{~L}$ & $\mathrm{~L}$ & 2.47 & 1.88 & 1.28 & 0.85 & 3.39 \\
7. Lucerne 2 (1990-92) & 4.70 & 2.18 & $\mathrm{~L}$ & $\mathrm{~L}$ & $\mathrm{~L}$ & 1.58 & 1.29 & 0.73 & 3.50 \\
8. Lucerne 2 (1990-93) & 4.62 & 2.26 & $\mathrm{~L}$ & $\mathrm{~L}$ & $\mathrm{~L}$ & $\mathrm{~L}$ & 1.23 & 0.80 & 3.32 \\
9. Continuous wheat & 4.78 & 2.17 & 2.17 & $\mathrm{~F}$ & 3.2 & 2.06 & 1.04 & 1.27 & 2.46 \\
1.s.d. $(P=0.05)$ & n.s. & n.s. & 0.14 & & n.s. & n.s. & n.s. & 0.26 & 0.28 \\
\hline
\end{tabular}


Table 3. The effect of duration of lucerne on grain protein of the following wheat crop

L, lucerne; F, fallow, no crop sown due to drought

\begin{tabular}{lrrrrrrrrr}
\hline Treatment & \multicolumn{9}{c}{ Wheat grain protein at 12\% moisture (\%) } \\
& 1988 & 1989 & 1990 & 1991 & 1992 & 1993 & 1994 & 1995 & 1996 \\
\hline 1. Lucerne 1 (1989) & 11.1 & $\mathrm{~L}$ & 11.4 & $\mathrm{~F}$ & 13.9 & 10.9 & 9.9 & 13.8 & 10.0 \\
2. Lucerne 1 (1989-90) & 10.4 & $\mathrm{~L}$ & $\mathrm{~L}$ & $\mathrm{~F}$ & 15.0 & 15.0 & 14.2 & 15.2 & 13.9 \\
3. Lucerne 1 (1989-91) & 10.9 & $\mathrm{~L}$ & $\mathrm{~L}$ & $\mathrm{~L}$ & 15.4 & 15.1 & 13.2 & 15.8 & 11.9 \\
4. Lucerne 1 (1989-92) & 10.4 & $\mathrm{~L}$ & $\mathrm{~L}$ & $\mathrm{~L}$ & $\mathrm{~L}$ & 16.1 & 12.0 & 15.9 & 12.1 \\
5. Lucerne 2 (1990) & 10.0 & 8.7 & $\mathrm{~L}$ & $\mathrm{~F}$ & 14.4 & 14.6 & 13.2 & 15.0 & 11.7 \\
6. Lucerne 2 (1990-91) & 10.2 & 8.4 & $\mathrm{~L}$ & $\mathrm{~L}$ & 15.2 & 14.6 & 12.1 & 14.7 & 10.8 \\
7. Lucerne 2 (1990-92) & 9.9 & 8.6 & $\mathrm{~L}$ & $\mathrm{~L}$ & $\mathrm{~L}$ & 16.1 & 13.4 & 15.5 & 11.7 \\
8. Lucerne 2 (1990-93) & 10.8 & 8.9 & $\mathrm{~L}$ & $\mathrm{~L}$ & $\mathrm{~L}$ & $\mathrm{~L}$ & 11.9 & 16.0 & 11.2 \\
9. Continuous wheat & 10.6 & 8.4 & 8.8 & $\mathrm{~F}$ & 12.1 & 9.9 & 9.3 & 12.9 & 9.3 \\
1.s.d. $(P=0.05)$ & 0.7 & n.s. & 1.1 & & 1.1 & 1.0 & 1.5 & 1.0 & 1.7 \\
\hline
\end{tabular}

1991-93 dry periods and possibly also the higher soil water in the profile before lucerne growth at Kingsthorpe since it was sown after fallow. Hirth et al. (2001) also measured higher water use efficiencies of lucerne production in Victoria, Australia (6.7-17.1 kg DM/ha.mm). However, the lucerne $\mathrm{N}$ yield in this study was similar to the values reported by Peoples et al. (2001).

Cumulative DM yields increased with lengthening of the lucerne ley period (Fig. 1a). Generally, lucerne DM increased linearly by $2.2 \mathrm{t} / \mathrm{ha}$.year, which was essentially similar to the lucerne DM in the 2-year lucerne-wheat rotation in the adjacent experiment (Dalal et al. 2004). For example, cumulative DM yields in the 4-year lucerne in phase 1 (1989-92) and in the 2-year lucerne-wheat rotation for the same 4-year period (Dalal et al. 2004) were $8.1 \mathrm{t} / \mathrm{ha}$ and $8.5 \mathrm{t} / \mathrm{ha}$, respectively. Moreover, the respective $\mathrm{N}$ yields (248 and $283 \mathrm{~kg} \mathrm{~N} / \mathrm{ha}$ ) were also similar. However, much larger DM but not $\mathrm{N}$ yield differences occurred in phase 2 of the 4-year lucerne and 2-year lucerne-wheat rotations; 7.3 and $6.3 \mathrm{t} / \mathrm{ha}(1990-93) \mathrm{DM}$ yields, and 223 and $214 \mathrm{~kg} / \mathrm{ha}$ of

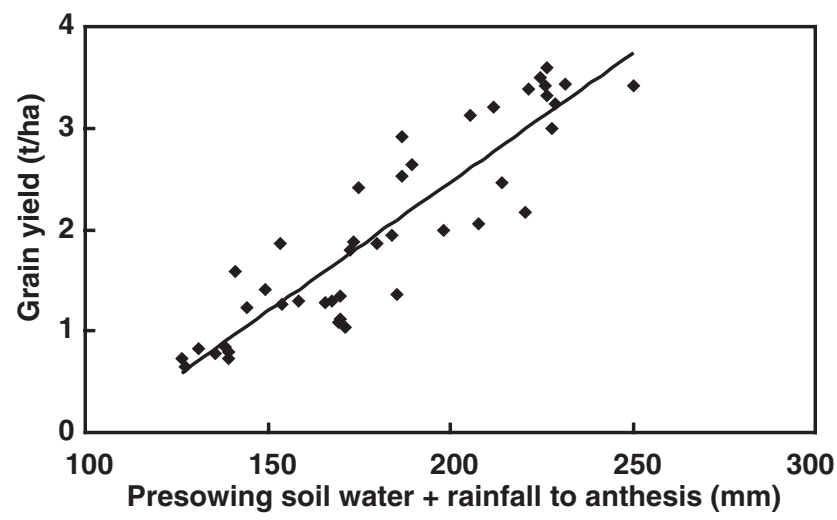

Figure 5. Relationship between the sum of presowing plant-available water in the soil profile (0-1.2 $\mathrm{m}$ depth) and rainfall from sowing to anthesis and wheat grain yield following lucerne leys of 1, 2, 3 and 4 years duration. The equation of the line is: $y=-2.63+0.026 x$ $\left(r^{2}=0.82, P<0.01\right)$.
$\mathrm{N}$ yields, respectively. This was primarily because of the low establishment and persistence of lucerne following wheat in the 2-year lucerne-wheat rotation during the dry periods of 1991-93, while the 4-year lucerne leys were established in 1989-90 during a period of favourable growth.

\section{Soil water and nitrate- $N$}

The progressive increase in residual nitrate- $\mathrm{N}$ in the subsoil following lucerne leys (Fig. 3) resulted from the low crop production and $\mathrm{N}$ removal during the low growing season rainfall from 1992 to 1995 . This was exacerbated by the extended fallow in 1991 when no sowing rain was received to sow wheat.

The plant-available water in the soil profile (generally below $0.6 \mathrm{~m}$ depth) following lucerne was lower than in wheat-wheat rotations in most years (Figs 3 and 4). In the extremely dry year (1995), wheat yields following lucerne leys were lower than those in the monoculture wheat without additional $\mathrm{N}$, while grain protein concentrations were $14 \%$ and above although the lucerne leys were terminated more than 2 years earlier. This suggests that the very high levels of accumulated nitrate-N may have been detrimental to wheat yields during low rainfall cropping seasons (van Herwaarden et al. 1998a).

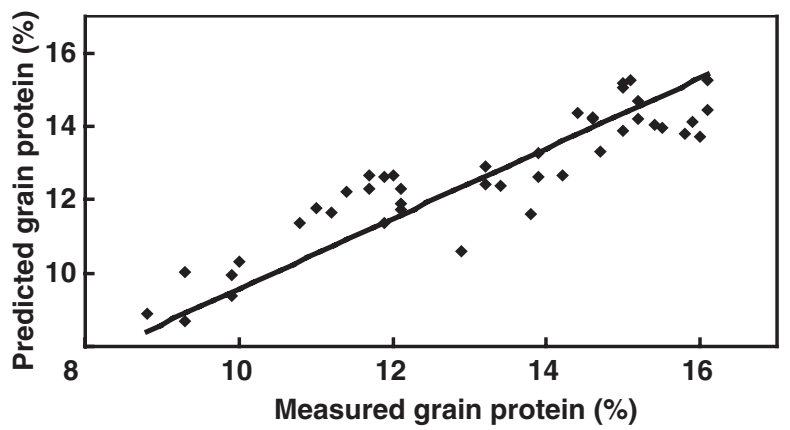

Figure 6. Wheat grain protein concentration, predicted from Dalal et al. (1997). The equation of the line is: $y=0.96 x\left(r^{2}=0.74, P<0.01\right)$. 
It appears that the drying effects of lucerne may last longer than one season in the eastern Australian subtropics when annual and crop growing season rainfalls are low. For example, lucerne leys terminated in October 1990, 1991, 1992 and 1993 after 1, 2, 3 or 4-year lucerne growth, depressed wheat grain yield in 1995 (sowing to anthesis rainfall of $<50 \mathrm{~mm}$ ). This is illustrated in Figures 3 and 4 for 4 -year lucerne leys, where total plant-available water at sowing as well as soil water in the deeper layer $(0.9-1.5 \mathrm{~m}$ depth) remained lower than wheat-wheat rotations for 3 to 4 years after termination of lucerne leys. Holford et al. (1998) also observed that a black Vertosol at Tamworth did not wet to field capacity 2.5 years after the termination of the lucerne ley. From their simulation studies, McCallum et al. (2001) also estimated that it may take up to 5 years after lucerne ley termination for the soil profile to attain water contents similar to that under continuous wheat.

\section{Wheat yield and protein}

Wheat yields following lucerne leys were affected only in the 1995 and 1996 seasons. In 1995, wheat yields were significantly lower and in 1996 yields were significantly higher following lucerne leys than in continuous wheat. Only exception was the 1-year lucerne ley from phase 1, which was terminated in 1989, and produced a higher yield than the wheat-wheat rotation in 1990 only. Cumulative wheat yields of 2 wheat crops following either 2 cycles of lucerne-wheat or continuous 2 lucerne- 2 wheat crops for the same wheat cropping years were similar (4.7 and $4.5 \mathrm{t} / \mathrm{ha}$ after lucerne phase 1 and 4.7 and 4.4 t/ha after lucerne phase 2 , respectively) (Dalal et al. 2004 and from Table 2, this study). Similar comparisons from 3 cycles of lucerne-wheat rotation and continuous 3 lucerne- 3 wheat crops showed cumulative wheat yields of 6.3 and $5.8 \mathrm{t} / \mathrm{ha}$, and 3.5 and $3.6 \mathrm{t} / \mathrm{ha}$, respectively. Only phase 1 of the continuous 4 lucerne4 wheat crops was complete, and hence no comparisons were made with 4 cycles of lucerne-wheat rotation.

Therefore, in a sequence of dry seasons after the termination of the lucerne leys, soil profile water recharge to rooting depth takes 2-3 years. Under these seasonal conditions, even longer duration of 3 years of lucerne, followed by 3 years of wheat crops would not reduce wheat
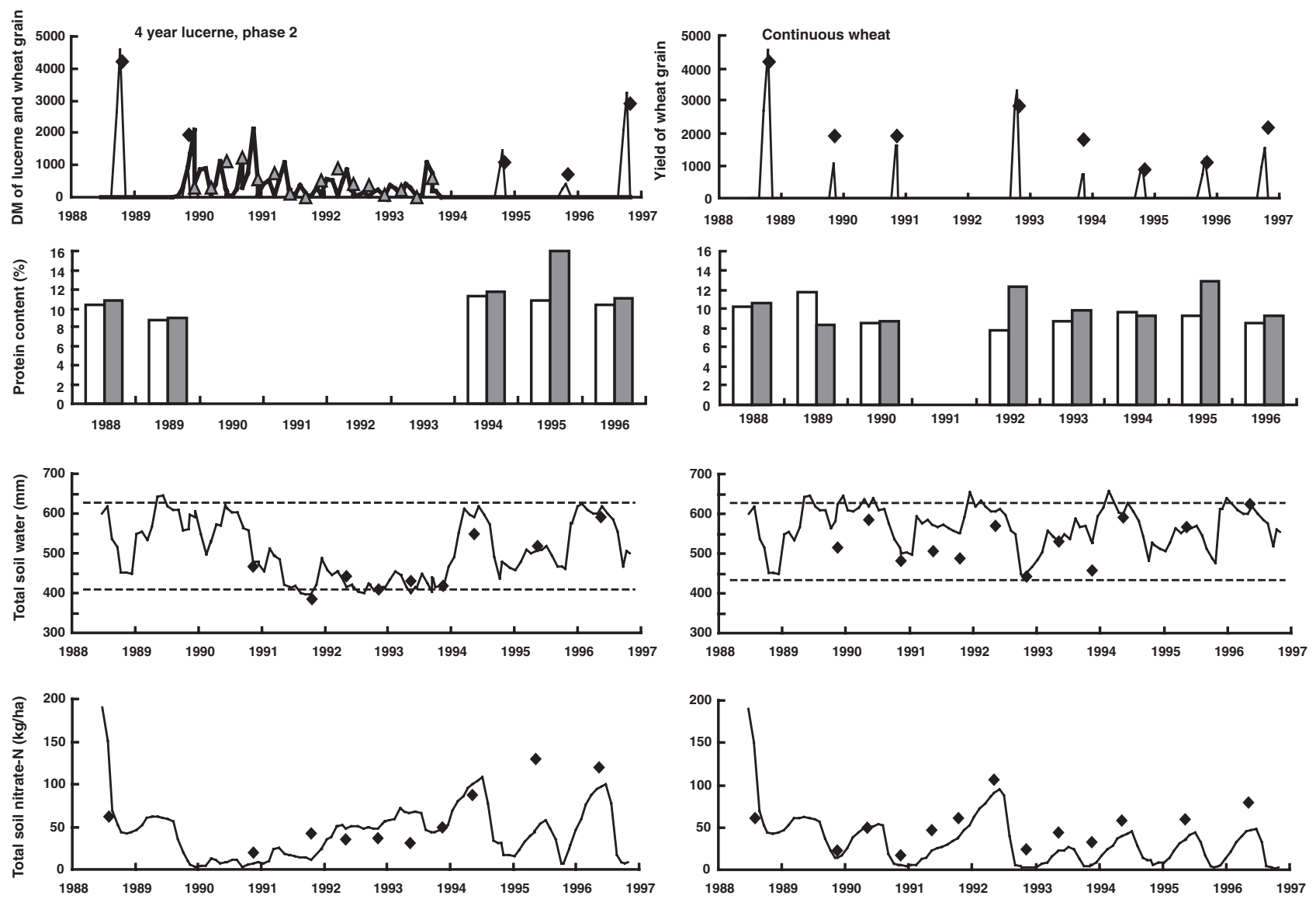

Figure 7. Simulation of wheat and lucerne yields, protein content of wheat at $12 \%$ moisture content, and soil water and nitrate- $\mathrm{N}$ to $1.5 \mathrm{~m}$ for the 4-year lucerne ley (phase 2) and the continuous wheat cropping. Symbols represent the measured data, and continuous lines the simulated data. For the simulations of the 2 systems, the model was initialized before the sowing of the wheat crops in 1988. The dashed lines on the soil water graphs represent the soil's drained upper limit and the lower limits for lucerne and wheat as used in the simulations. 
yield variability (Table 2), as was experienced in 2-year lucerne-wheat rotations earlier by Dalal et al. (2004).

Although wheat yield benefits following lucerne leys were highly variable, grain protein contents were consistent and increases ranged from 7 to $63 \%$ (Table 3 ). In spite of the large wheat yield variability in lucerne-wheat rotations, grain protein concentrations were higher than in wheat-wheat rotations and usually higher than those obtained in wheat-wheat rotations with annual applications of $50 \mathrm{~kg} \mathrm{~N} / \mathrm{ha}$ of fertiliser (Dalal et al. 2004).

Average water use efficiency $[\mathrm{kg}$ grain $/ \mathrm{ha} . \mathrm{mm}=$ grain yield in $\mathrm{kg} / \mathrm{ha}$.(mm of soil water at sowing - soil water at harvest in $0-1.2 \mathrm{~m}$ depth) + in-crop rainfall] was $9.3 \pm 3.2$ (range 4.2-14.6), a value similar to that in the 2-year lucerne-wheat rotation (Dalal et al. 2004), and within the range (4.85-13.7) reported by Hirth et al. (2001) in Victoria. Our average value is lower than that $(12.7 \mathrm{~kg} / \mathrm{ha} . \mathrm{mm})$ reported by French and Schultz (1984) for wheat grown in South Australia, however, they did not consider the presowing plant-available water in soil and variation in vapour pressure deficit between seasons, which were generally small in their environments (Angus and van Herwaarden 2001). We also did not account for runoff and leaching below the root-zone in calculating water use efficiency above. However, these factors were considered in simulating the wheat yields by the APSIM model.

Although wheat grain yield was poorly correlated with presowing plant-available water or soil nitrate concentrations, wheat grain protein (Table 3) was closely correlated with the ratio of plant-available water and nitrate-N $\left(r^{2}=0.74\right.$, Fig. 6$)$, using relationships developed by Dalal et al. (1997). Van Herwaarden et al. (1998b) observed the negative relationship between water soluble carbohydrates at anthesis and wheat grain protein, indicating that while water soluble carbohydrates and consequently grain yield is primarily determined by total available water, grain protein is determined by plant-available water and mineral $\mathrm{N}$ supply (Strong et al. 1996; Dalal et al. 1997). We also observed that the lower the ratio of plant-available water to nitrate-N in the soil profile at sowing, higher the amount of nitrate- $\mathrm{N}$ in the soil was found after harvest $\left(r^{2}=0.72\right)$. It appears that limited plant-available water restricted root length density, and hence $\mathrm{N}$ uptake by wheat. Thus, the impact of water as well as $\mathrm{N}$ on wheat yields and grain protein must be considered following lucerne leys in rotation with wheat.

\section{Predicting the impacts of a lucerne ley on subsequent crops}

The results from this experiment show again that there are 2 opposing effects of lucerne on subsequent cereal crops. The positive effect is associated with improved $\mathrm{N}$ supply after the legume; the negative effect is caused by the greater depletion of subsoil water reserves by lucerne. Year-to-year variability in rainfall will determine the importance of the latter. Experimentation will always be inadequate to answer questions concerning the magnitude and frequency of these effects, especially in locations where rainfall variability is high. On the other hand, models, used with long-term climatic records, are well suited to address such issues (Keating et al. 2003).

Figure 8 shows the results from such a simulation study where a 2-year lucerne ley was removed on 1 October. The model predicts a declining influence on nitrate- $\mathrm{N}$ over time, although there is a $50 \%$ probability that the effect is still worth about $50 \mathrm{~kg} / \mathrm{ha}$ of $\mathrm{N}$ to the third crop. The deficit in soil water also decreases over time but there remains a $40 \%$ chance that the profile will not have fully recharged by the time of the third wheat crop after lucerne.

\section{Optimum lucerne ley duration in southern Queensland}

The lucerne ley to meet the $\mathrm{N}$ needs of wheat in rotation, while maintaining soil $\mathrm{N}$ levels, can be estimated as follows (Dalal et al. 1991): (dN/dt) $\mathrm{t}_{1}=-\mathrm{k}_{1} \mathrm{~N}_{\mathrm{e}}+\mathrm{A}_{1}$ for changes in soil $\mathrm{N}$ following lucerne and $(\mathrm{dN} / \mathrm{dt}) \mathrm{t}_{\mathrm{w}}=-\mathrm{k}_{\mathrm{w}} \mathrm{N}_{\mathrm{e}}+\mathrm{A}_{\mathrm{w}}$ for changes in soil $\mathrm{N}$ following wheat.

Since after lucerne-wheat rotation, soil $\mathrm{N}$ concentration is unchanged, that is, $(\mathrm{dN} / \mathrm{dt})=0$,

$$
\left(-\mathrm{k}_{\mathrm{w}} \mathrm{N}_{\mathrm{e}}+\mathrm{A}_{\mathrm{w}}\right) \mathrm{t}_{\mathrm{w}}+\left(-\mathrm{k}_{\mathrm{l}} \mathrm{N}_{\mathrm{e}}+\mathrm{A}_{1}\right) \mathrm{t}_{\mathrm{l}}=0
$$
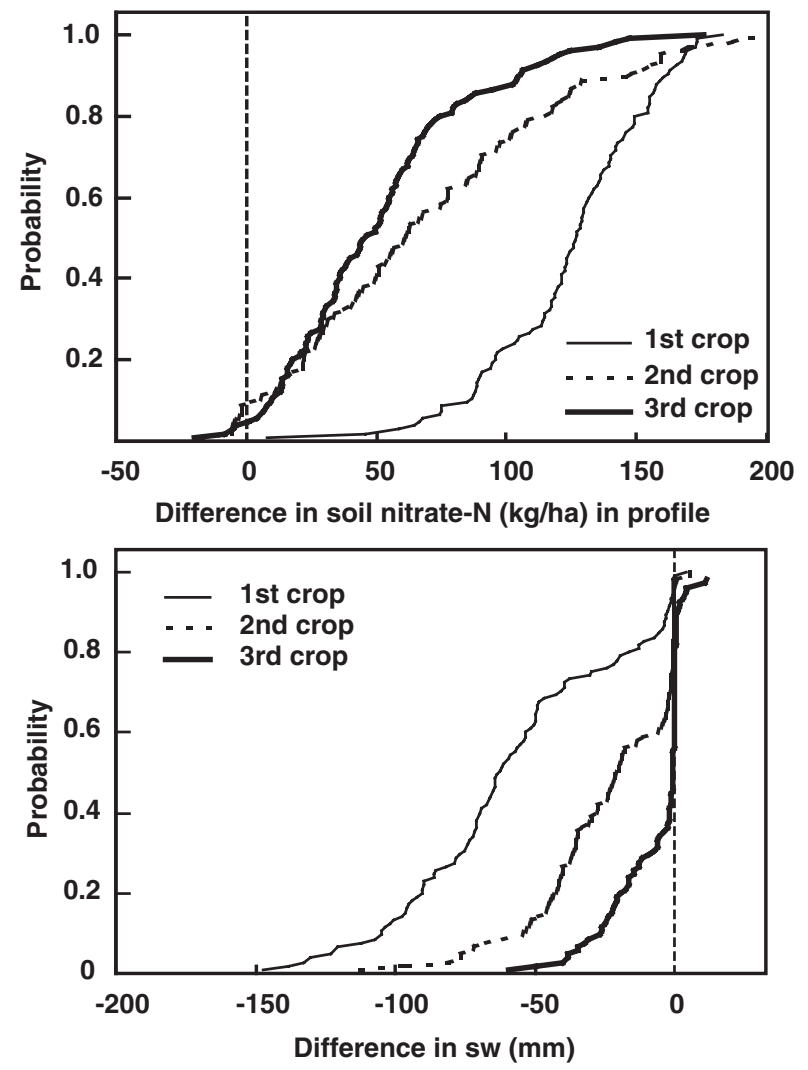

Figure 8. Predicted effect of a 2-year lucerne ley, removed in October, on the nitrate- $\mathrm{N}$ and soil water at $1.5 \mathrm{~m}$ depths at the time of sowing subsequent wheat crops (cumulative probability distribution). The data are shown relative to continuous wheat cropping. 
and on rearranging the above equation, it leads to

$$
\mathrm{t}_{\mathrm{w}} / \mathrm{t}_{\mathrm{l}}=\left(\mathrm{A}_{1}-\mathrm{k}_{\mathrm{l}} \mathrm{N}_{\mathrm{e}}\right) /\left(\mathrm{k}_{\mathrm{w}} \mathrm{N}_{\mathrm{e}}-\mathrm{A}_{\mathrm{w}}\right)
$$

where $t_{1}$ or $t_{w}$ is the duration of lucerne or wheat required to maintain soil $\mathrm{N}$ at equilibrium $\left(\mathrm{N}_{\mathrm{e}}\right), \mathrm{k}_{1}$ and $\mathrm{k}_{\mathrm{w}}$ are the rates of loss of $\mathrm{N}$, and $\mathrm{A}_{1}$ and $\mathrm{A}_{\mathrm{w}}$ are the rates of addition of $\mathrm{N}$ during pasture and cropping phases, respectively. For the adjoining Warra experiment, using equation 2, Dalal et al. (1991) estimated that for 1 wheat crop in rotation, a lucerne ley needs to add to soil $80 \mathrm{~kg} \mathrm{~N} /$ ha.year from a 1-year lucerne ley and $50 \mathrm{~kg} \mathrm{~N} /$ ha.year from a 2-year lucerne ley. Alternatively, a lucerne ley adding $140 \mathrm{kgN} / \mathrm{ha}$ can sustain 2 wheat crops. These values can be converted into the lucerne DM required for 1-year rotation with wheat, using Peoples et al. (2001) value of fixed $\mathrm{N}$ of $20 \mathrm{~kg} / \mathrm{t}$ of lucerne $\mathrm{DM}$. That is, the lucerne DM required for 1 wheat crop would be $4 \mathrm{t} / \mathrm{ha}$.year for a 1-year lucerne ley or $2.5 \mathrm{t} / \mathrm{ha}$.year for a 2-year lucerne ley or $7 \mathrm{t} / \mathrm{ha}$ lucerne DM for 2 wheat crops. In our study, lucerne DM varied from $0.8 \mathrm{t} / \mathrm{ha}$ in 1991 to $3.7 \mathrm{t} / \mathrm{h}$ a in 1990 , with a 4-year lucerne ley just exceeding a cumulative DM of $7 \mathrm{t} / \mathrm{ha}$. The lucerne ley for the $\mathrm{N}$ benefits to the following wheat crop, therefore, depends on the total lucerne DM production rather than a fixed period. However, presowing plant-available water is as much or more important than enhanced $\mathrm{N}$ supply for wheat production since in-crop rainfall, especially from sowing to anthesis, is highly variable, and thus could restrict the $\mathrm{N}$ utilisation by wheat following a lucerne ley.

A major decision for farmers will be when to remove the ley. There will be a temptation to utilise any growth of the ley in the spring-early summer thereby delaying its removal. Table 4 summarises the predicted effects of removing the ley on 16 December rather than 1 October. The effects of delaying the removal of lucerne ley until December are more severe in terms of water available for the next crop than for nitrate-N.

However, it would be overly simplistic to address these matters solely in terms of water and N. Ultimately there is a need to consider the economics of the whole system including the ley phase. Placing an economic value on the

Table 4. Predicted effects of removing lucerne ley in either October or December on average nitrate-N and soil water deficit in $1.5 \mathrm{~m}$ profile at time of planting subsequent wheat crops

Effects of lucerne-wheat rotations are expressed relative to wheat-wheat rotation

\begin{tabular}{lccc}
\hline Removal of ley & 1st crop & 2nd crop & 3rd crop \\
\hline & Nitrate $-N(\mathrm{~kg} / \mathrm{ha})$ & \\
1 October & 124 & 68 & 51 \\
16 December & 102 & 74 & 56 \\
& Soil water deficit $(\mathrm{mm})$ & \\
1 October & 57 & 23 & 7 \\
16 December & 94 & 41 & 20 \\
\hline
\end{tabular}

lucerne production in farming systems that have no animals is a deterrent to undertaking such an analysis. The reduction in the return for wheat after 2 years of lucerne pasture, due to the moisture deficit, was $22 \%$ due directly to grain yield penalty measured in 1992. However, this reduction could potentially be offset by the $25 \%$ increase in grain protein after the pasture. In fact, in the early to mid 1990s, when premium payments for wheat protein (Australian Prime Hard classification) were much greater than in recent years, returns for wheat after pasture would have been recouped due to the $29-38 \%$ increase in the value of the higher protein grain produced after lucerne (15.1\%) compared with that of continuous wheat (12.1\%). The lower grain values for a similar protein increase in recent years $(9 \%$ projected by AWB for 2003 crop) and the impact of reduced grain size after pasture also downgrading the wheat would suggest that in the current market the yield penalty would probably not be recouped by any changes in grain classification. These assessments are corroborated by Hirth et al. (2001) from their economic evaluation of variable lucerne leys in lucerne-wheat rotations and 2-year lucerne-wheat rotations by Dalal et al. (1996).

\section{Conclusion}

The benefits from lucerne in lucerne-wheat rotations were due to $\mathrm{N}$ accretion, provided that moderate to good amounts of stored soil water were available and that growing season rainfall occurred. Wheat yields and proteins were increased by incorporating lucerne in rotation and significantly outperformed wheat-wheat rotations without fertiliser $\mathrm{N}$ application. In low rainfall seasons, however, even when the period of lucerne ley is increased from 1 to 4 years, wheat yields in lucerne-wheat rotations are depressed and grain protein levels are elevated (due to higher nitrate- $\mathrm{N}$ concentrations), resulting in lower wheat yields as well as higher yield variability, than in wheat-wheat rotations. These effects could persist for a number of low rainfall seasons, thus adversely affecting the sustainable cereal production. However, it is possible to regulate $\mathrm{N}$ mineralisation from legume pastures by including grasses in legume leys (Hossain et al. 1996b). This variation and its effects on wheat yields and grain proteins are reported in a subsequent paper.

The APSIM model was able to predict the effects of the lucerne leys on soil water and mineral-N and the growth of the subsequent wheat crops. The recharge of the soil profile after the lucerne is very dependent on rainfall. However the model, in conjunction with long-term climatic data, provides a means of extrapolation from the experimental data and in particular allows key decisions pertinent to the inclusion of lucerne into farming systems to be addressed. These include management issues such as the length of the ley and when the lucerne ley should be terminated. 


\section{Acknowledgments}

We thank Mr Peter Bock and Mr Tim Reid for providing land for the Warra Experiment, the Queensland Wheat Committee and Grains Research and Development Corporation for the funding support, Mrs J. Glasby and Mrs A. Pumfrey for soil and plant analysis, and Dr R. A. Fischer, Mr D. Lloyd and 3 reviewers for comments and valuable suggestions.

\section{References}

Angus JF, van Herwaarden AF (2001) Increasing water use and water use efficiency in dryland wheat. Agronomy Journal 93, 290-298.

Armstrong RD, McCosker K, Johnson SB, Walsh KB, Millar G, Kuskopf B, Standley J, Probert ME (1999) Legume and opportunity cropping systems in central Queensland. 1. Legume growth, nitrogen fixation, and water use. Australian Journal of Agricultural Research 50, 909-924. doi:10.1071/AR98100

Best EK (1976) An automated method for the determination of nitratenitrogen in soil extracts. Queensland Journal of Agricultural and Animal Sciences 33, 161-166.

Crooke WM, Simpson WE (1971) Determination of ammonium in Kjeldahl digests of crops by an automated procedure. Journal of the Science of Food and Agriculture 22, 9-10.

Dalal RC, Mayer RJ (1986a) Long-term trends in fertility of soils under continuous cultivation and cereal cropping in southern Queensland. 1. Overall changes in soil properties and trends in winter cereal yields. Australian Journal of Soil Research 24, 265-279.

Dalal RC, Mayer RJ (1986b) Long-term trends in fertility of soils under continuous cultivation and cereal cropping in southern Queensland. II. Total organic carbon and its rate of loss from the soil profile. Australian Journal of Soil Research 24, 281-292.

Dalal RC, Mayer RJ (1986c) Long-term trends in fertility of soils under continuous cultivation and cereal cropping in southern Queensland. $\mathrm{V}$. Rate of loss of total nitrogen from the soil profile and changes in carbon-nitrogen ratios. Australian Journal of Soil Research 24, 493-504.

Dalal RC, Sahrawat KL, Mayer RJ (1984) Inclusion of nitrate and nitrite in the Kjeldahl nitrogen determination of soils and plant materials using sodium thiosulphate. Communications in Soil Science and Plant Analysis 13, 75-86.

Dalal RC, Strong WM, Weston EJ, Cahill MJ, Gaffney J, Cooper JE, Lehane KJ, King AJ (1996) Sustainability and profitability: a case study from the Warra Experiment. In 'Proceedings of the 8th Australian agronomy conference'. (Ed. M Asghar) pp. 181-184. (The Australian Society of Agronomy Inc.: Toowoomba, Qld)

Dalal RC, Strong WM, Weston EJ, Cooper JE, Lehane KJ, King AJ, Chicken CJ (1995) Sustaining productivity of a Vertosol at Warra, Queensland, with fertiliser, no-tillage, or legumes. 1. Organic matter status. Australian Journal of Experimental Agriculture 35, 903-913.

Dalal RC, Strong WM, Weston EJ, Cooper JE, Thomas GA (1997) Prediction of grain protein in wheat and barley in a subtropical environment from available water and nitrogen in Vertosols at sowing. Australian Journal of Experimental Agriculture 37, 351-357. doi:10.1071/EA96126

Dalal RC, Strong WM, Weston EJ, Cooper JE, Wildermuth GB, Lehane KJ, King AJ, Holmes CJ (1998) Sustaining productivity of a Vertosol at Warra, Queensland, with fertilisers, no-tillage, or legumes. 5. Wheat yields, nitrogen benefits and water-use efficiency of chickpea-wheat rotation. Australian Journal of Experimental Agriculture 38, 489-501. doi:10.1071/EA98027
Dalal RC, Strong WM, Weston EJ, Gaffney J (1991) Sustaining multiple production systems. 2. Soil fertility decline restoration of cropping lands in sub-tropical Queensland. Tropical Grasslands 25, 173-180.

Dalal RC, Weston EJ, Strong WM, Lehane KJ, Cooper JE, King AJ, Holmes CJ (2004) Sustaining productivity of a Vertosol at Warra, Queensland, with fertiliser, no-tillage and legumes. 7. Yield, nitrogen and disease-break benefits from lucerne in a two-year lucerne-wheat rotation. Australian Journal of Experimental Agriculture 44, 607-616. doi:10.1071/EA02115

French RJ, Schultz JE (1984) Water use efficiency of wheat production in a Mediterranean-type environment. 1. The relation between yield, water use and climate. Australian Journal of Agricultural Research 35, 743-764.

Hirth JR, Haines PJ, Rodley AM, Wilson KF (2001) Lucerne in crop rotations on the Riverine Plains 2. Biomass and grain yields, water use efficiency, soil nitrogen, and profitability. Australian Journal of Agricultural Research 52, 279-293. doi:10.1071/AR00006

Holford ICR (1981) Changes in nitrogen and organic carbon of wheatgrowing soils after various periods of grazed lucerne, extended fallowing and continuous wheat. Australian Journal of Soil Research 19, 239-249.

Holford ICR, Crocker GJ (1997) A comparison of chickpeas and pasture legumes for sustaining yields and nitrogen status of subsequent wheat. Australian Journal of Agricultural Research 48, 305-315. doi:10.1071/A96072

Holford ICR, Schweitzer BE, Crocker GJ (1998) Comparative effects of subterranean clover, medic, lucerne, and chickpea in wheat rotations, on nitrogen, organic carbon, and moisture in two contrasting soils. Australian Journal of Soil Research 36, 57-72. doi:10.1071/S97036

Hossain SA, Dalal RC, Waring SA, Strong WM, Weston EJ (1996a) Comparison of legume-based cropping systems at Warra, Queensland. I. Soil nitrogen and organic carbon accretion and potentially mineralisable nitrogen. Australian Journal of Soil Research 34, 273-287.

Hossain SA, Strong WM, Waring SA, Dalal RC, Weston EJ (1996b) Comparison of legume-based cropping systems at Warra, Queensland. II. Mineral nitrogen accumulation and availability to subsequent wheat crop. Australian Journal of Soil Research 34, 289-297.

Hossain SA, Waring SA, Strong WM, Dalal RC, Weston EJ (1995) Estimates of nitrogen fixations by legumes in alternate cropping systems at Warra, Queensland, using enriched ${ }^{15} \mathrm{~N}$ dilution and natural ${ }^{15} \mathrm{~N}$ abundance techniques. Australian Journal of Agricultural Research 46, 493-505.

Keating BA, Carberry PS, Hammer GL, Probert ME, Robertson MJ et al (2003) An overview of APSIM, a model designed for farming systems simulation. European Journal of Agronomy 18, 267-288. doi:10.1016/S1161-0301(02)00108-9

Lloyd DL, Hilder TB (1978) Growth of lucerne in relation to soil water. Queensland Wheat Research Institute Biennial Report 1976-1978. Queensland Department of Primary Industries, Toowoomba. p. 41.

McCallum MH, Connor DJ, O'Leary GJ (2001) Water use by lucerne and effect on crops in the Victorian Wimmera. Australian Journal of Agricultural Research 52, 193-201. doi:10.1071/AR99164

Page KL, Dalal RC, Menzies NW, Strong WM (2002) Nitrification in a Vertisol subsoil and its relationship to the accumulation of ammonium-nitrogen at depth. Australian Journal of Soil Research 40, 727-735. doi:10.1071/SR01087

Peoples MB, Baldock JA (2001) Nitrogen dynamics of pastures: nitrogen fixation inputs, the impact of legumes on soil nitrogen fertility, and the contributions of fixed nitrogen to Australian farming systems. Australian Journal of Experimental Agriculture 41, 327-346. doi:10.1071/EA99139 
Peoples MB, Bowman AM, Gault RR, Herridge DF, McCallum MH, McCormick KM, Norton RM, Rochester IJ, Scammell GJ, Schwenke GD (2001) Factors regulating the contributions of fixed nitrogen by pasture and crop legumes to different farming systems of eastern Australia. Plant and Soil 228, 29-41. doi:10.1023/ A: 1004799703040

Probert ME, Dimes JP, Keating BA, Dalal RC, Strong WM (1998) APSIM's water and nitrogen modules and simulation of the dynamics of water and nitrogen in fallow systems. Agricultural Systems 56, 1-28. doi:10.1016/S0308-521X(97)00028-0

Strong WM, Dalal RC, Weston EJ, Cooper JE, Lehane KJ, King AJ, Chicken CJ (1996) Sustaining productivity of a Vertosol at Warra, Queensland, with fertiliser, no-tillage and legumes. 2. Long-term fertiliser needs to enhance wheat yields and grain protein. Australian Journal of Experimental Agriculture 36, 665-674.

Turpin JE, Carberry PS, McCown RL, Probert ME (1998) Simulation of legume-cereal systems using APSIM. Australian Journal of Agricultural Research 49, 317-328. doi:10.1071/A97070

van Herwaarden AF, Angus JF, Farquhar GD, Howe GN, Richards RA (1998a) 'Haying-off', the negative grain yield response of dryland wheat to $\mathrm{N}$ fertiliser. I. Biomass, grain yield, and water use. Australian Journal of Agricultural Research 49, 1067-1081. doi:10.1071/A97039 van Herwaarden AF, Angus JF, Richards RA, Farquhar GD (1998b) 'Haying-off', the negative grain yield response of dryland wheat to $\mathrm{N}$ fertiliser. II. Carbohydrate and protein dynamics. Australian Journal of Agricultural Research 49, 1083-1093. doi:10.1071/ A97040

Weston EJ, Dalal RC, Strong WM, Lehane KJ, Cooper JE, King AJ, Holmes CJ (2002) Sustaining productivity of a Vertosol at Warra, Queensland, with fertiliser, no-tillage and legumes. 6. Production and nitrogen benefits from annual medic in rotation with wheat. Australian Journal of Experimental Agriculture 42, 665-674. doi:10.1071/EA02004

Weston EJ, Doughton JA, Dalal RC, Strong WM, Thomas GA, Lehane KJ, Cooper JC, King AJ, Holmes CJ (2000) Managing longterm fertility of cropping lands with ley pastures in southern Queensland. Tropical Grasslands 34, 169-176.

Whitehouse MJ, Littler JW (1984) Effect of pasture on subsequent wheat crops on a black earth soil of the Darling Downs. II. Organic $\mathrm{C}$, nitrogen and $\mathrm{pH}$ changes. Queensland Journal of Agriculture and Animal Sciences 41, 13-20.

Received 8 August 2003, accepted 8 December 2003 